\title{
Perspectives of the Science of Criminology
}

\author{
Dr. Bledar Mustafaraj \\ Public Prosecutor \\ Prosecutor's Office of Elbasan Judicial District, Albania \\ Lecturer (Part - time), University "Aleksandër Xhuvani”, Elbasan, Albania
}

\begin{abstract}
The object of criminology is to investigate and explicate conducts contradicting social order. The roots of this science originate from the thoughts of the first generation of sensible men who were able to reflect over aggressive actions, suchlike murders or any other criminal conducts breaking social rules. In terms of moral, religious, philosophical or political outlook, the inception of criminology is even more ancient whereas from the doctrinal point of view, the origin of this science has been considered the XIX century. Later on, from the middle of the past century and on, while it was developing gradually, issues related to criminal offenses and felons were treated legally, considerations that had an effect into the future of the science in word. Criminal act may be related to political, legal, constabulary, medical, psychological or sociological issues. Deviation and criminal offenses should be analysed in terms of all these domains and precisely this is where criminology should be justified as a science, considering the pro and contrary attitudes, regarding its role as an auxiliary discipline. Therefore, it is crucial for the science of criminology not to experience any critical situations of other social sciences and not get apart from its base ideals. It should be linked more with the reality, including all actors, the society and its values, culture, etc., and respond to questions related to its own object of study, acknowledging limitations and fully playing its role in an unstable society in continuous transformation while considering the effects of its intrusions.
\end{abstract}

Keywords: Criminology, Positive School, crises, paradigms of criminology, the future of criminology.

\section{Introduction}

As a science, criminology originates in the period human society took shape, when the first generation of sensible men were able to reflect over aggressive actions of an individual or a group of individuals, suchlike murders or any other felons whose conducts used to break social rules. Individuals who primarily reflected over felons conducts were the very first criminologists. Consequently, finding out the meaning of and understanding conducts which were considered antagonistic to social order, make up the object of the science of criminology.

Evidence supports the fact cited above that this science originates from ancient times; pre-historic paintings found in caves show aggressive conducts against vulnerable members of the tribes (Parmelee, 1918, 2013). It cannot be ascertained whether these conducts had a religious, educative or criminal background, however, there is no doubt that they convey the idea of a collective reflection to these events, characteristic for that period of time.

In the course of time, mankind gave shape to and consolidated clues about criminal acts and their significance. In a moral, religious and philosophical or political point of view, the genesis of criminology goes back to ancient times, whereas, in terms of doctrine, the origin of this science is the XIX century (Marotta, 2015). Three are the main figures who founded the school of criminology, (The Positive School) in 1880; Lombroso (1835-1909), Garofalo (1851-1934) and Ferri (1856-1929). It is because of them that we maintain concepts characterizing the born felons, suchlike high forehead, huge jaws, and elevated cheek bones. Are felons particular human beings? This was the question prevailing at that time and still persisting even for the present, while staring at the photos of some ill-famed and most wanted felons. Lombrosos's idea of the inner features of conduct continues to be acceptable, to a certain extent, even more substantial and persisting at present, in the theories of personality, the genetics of human conducts or individual rationality (rational actions). 
Founding fathers of criminology determined the circle of individuals that should be object of research; felons, the criminal acts and their social background, focusing on the methodical researching of the criminal acts which continue to exist in the society, need to be analyzed and which, definitely, are unavoidable.

Even though Lombroso overestimated biological affects by determining felons as atavist and indisposed beings, stigmatized by a series of bodily and moral anomalies, by means of the theory of born felons he revealed the historical and factual state of the individuals who might be victims of social circumstances they evolved in, rather than being guilty of their own conscious acts or free judgment (as represented by classical school) (Lombroso, 1896). On the other side, Ferri studied criminal phenomena under a clear-cut social context. According to him, Lombroso gave too much significance to anthropological and anthropometrical factors while neglecting the sociological and psychological ones. In his work, "Criminal Sociology" $(1884,1905)$, this author emphasized the social origin of felony (Ferri, 1953).

In 1885 Garofalo introduced the name of the new science under the title of his work "Criminology - A Study on the Nature of Crime and the Theory of Conviction". For the Italian jurist, the other two founders of the school focus only in the figure of felons renders the study of crimes more difficult; according to Garofalo, it should be considered as a positive criminological fact and not be treated as juridical definition (Garofalo, 1890). In this point of view, the natural penal acts (the basis of which is the cession of the moral, altruist and natural sentiments of human beings and those of the society as a whole), are the positive definition conveyed by naturalist researchers and by means of scientific inquiry. This study reveals the strategy of the just-born and ever empowering science of criminology, emphasizing that, in addition to the notion of felons, the notion of the penal acts should be defined by criminology, as well. Positivism deals with the systematical study of the observable and experimental phenomena in which, every piece of evidence that cannot be verified in empirical way does not make up a positive fact, but simply an opinion or a conjecture devoid of any scientific significance (Lilly, Cullen, Ball, 2015). Considered from this point of view, felons and the crime, as real units, can be subjected to positive analyses, can be observed and measured, their root causes can be studied and their effects can be reduced or mitigated: finally, the rules they perform can be fully revealed. To original positivism, the main cause of the criminal offense is the felons. What are felons? How can they become such people? What are their features? These are the fundamental issues of positivist criminology, whereas answers to these questions are obtained by the same epistemological and methodical principles used in other sciences suchlike biology, physics and mathematics (Kaiser, 1988).

The main contribution of the School of Chicago (10s and 20s of the XX century), dealt with the role of the figure of deviants into understanding deviation of the criminal offense; it was a qualitative sociology emphasizing individual subjectivism, consistent to the epistemological principles of Weber and Simmel (Burke, 2014). This current analyzes various clues and considers deviation as an adaptation strategy in the social ambiance, so making a great contribution to dismissing the theory of felony as physiological pathology, as product of lab studies about deviants as well as their consideration as mere statistical figures. This current has also contributed to the definition of deviation as a normal fact/subject whose normality is not merely a statistical issue in the Durkheimian point of view; on the contrary, it consists of expectations taking advantage of circumstances (Marotta, 2015). Deviation is an acquired strategy (a formulated one not a natural strategy), to be faced with the reality. Felons are as humane as other human beings and their presence is not related to any anthropological variety, or to any variation of anomalies or any kinds or disease (Ponti and Merzagora Betsos, 2008).

The positivist paradigm entails criminality as a product of various social and cultural strata. The functionalist current (prevailing to the end of ' 30 s up to '60s), emphasized culture as the main factor, determining crime as a result of losing certain values or as effect of the other ones; on the other side, the critical-radical current focused on the role of economic structures and determined crime as product of the capitalist system (Bernard, Snipes, Gerould, 2010). These currents highlight the fact that understanding root causes of crime is a quite realizable aim since the causes can be found in the society; if the social-cultural conditions change or ameliorate the level of crime falls. Between the social wellbeing, in its widest meaning, and crime, persists a mutual and causal relationship (Mantovani, 1984).

Merton's ideas over the social structure and anomie (formulated in 1938 and spread in the following decade), consist, in my personal judgment, the best efforts explaining the observable relationships among social and cultural structures and deviants' and criminal conducts (Merton, 1968). Those ideas served as support to the theories of culture in the 50s, having Cohen (1955) and Cloward and Ohlin (1960) as their main representatives and they still continue to persist in the modern currents of criminology (Cohen, 1955), (Cloward and Ohlin, 2011). 
During 60 s and the beginnings of 70 s, the theories of social stigmatization/reaction emerged and spanned (having Becker and Lemert as their main representatives) (García-Pablos de Molina, 2013). They consider felons as full, active subjects having too much to show about themselves; theories focus especially on social control. There is an interaction between deviants and the society, the last one being a strong subject regarding this issue, whereas deviants are the weakest subjects. It is the social group which determines what is permissible and which is forbidden as well the etiquettes bearing real effects (Becker, 1997). Actually, in the trinomial felon-crime-social reaction, the most stable are the society and its reaction. Penal acts and felons are the etiquette, social definitions applied by weak subjects in the course of their criminal career. Approaches to interaction served to the leftist and radicals to allege that it is the state and its main tool, the Penal Law which gives shape, through definitions, to both criminal acts and felons, in which the first is an expression of the capitalist order whereas the second is a way of stamina and a response to the exploitation of people, which is part of the system's nature. This kind of response, according to Austin Turk, one of the most distinguished representatives of this current, has been prone to failure, nonsense and isolation, since felons, over whom the state focuses its stigmatizing action, are generally young people, inexperienced, poor and part of the ethnic minorities, therefore, weak subjects (Burke, 2014). These years also mark the beginning of the historical period which cannot be defined clearly, so, the epithet post is randomly used about it; post-industrial economic and social field and post-modern cultural and identity period (Gassin, Cimamonti, Bonfils, 2011). This phase has been characterized by the shift from the economy of production to that of services and consumption; means of wide communication transfer to centers of power, the importance of the great social, political and religious ideologies diminished; after the fall of the Berlin Wall, in 1989, when "end of the history" was predicted (Jones 2013) and internet transferred into a global means of communication for the global community, giving way to a new kind of society, the network society (Ponti, Merzagora Betsos, 2008). In my personal opinion, this era is characterized by individualist inclinations, where individuals focus into themselves, in the form of psychological self-esteem and caring for their complexion and appearance as well as enjoying the present as if it were the sole moment of life (Giddens, 1991).

The post-modernist period causes disappointment regarding general issues, which become relative. Others use the term 'late modernism', or 'second modernism'; according to these authors the actual period, rather than being a new era, is a time-period where conditions and effects which began in XVII century augment and update continuously (Giddens, 1991). According to Vattimo, events are not important anymore but, the way they are presented and shown are significant, especially those transmitted by means of communication showing virtual realities (Vattimo, 2011). The epistemology of late modern time has already dropped the possibility for a general-postulate social science; on its own, the historical development opposes the cause-effect relationships determined by positivism (both left and right positivism), for which concrete, limited and casual knowledge are sufficient (Vattimo, 2009). This conviction entails casting doubts on and even giving traditional paradigms up, in the least, they imply taking biased attitudes. This reality of the great epistemological paradigms is related to what has been considered as the etiological crises of criminology originating in the mistrust of late modernism which has been added a series of concrete situation disputing previous situations (Taylor, 1999):

- Reduction in the figures of criminality have been noticed in periods of unemployment and increasing poverty, whereas, on the other side, criminal acts have increased in periods of economic wellbeing.

- Members of the middle and rich classes of the society commit criminal offenses to the same extent or even more than members of the poor classes.

- There are more criminal acts in developed areas compared to the poor areas.

In the period following World War Two and up to '70s, the so-called First World was founded, for which the decades of the ' 50 s and ' 60 s were characterized by stable development. During this period, the positivist paradigm, especially the socialdemocratic one, considered unstable social conditions as the root causes of anti-social conducts. Unemployment fell down to minimal levels, almost fell down to historically minimal levels, social welfare expenses grew, and so did the official sheltering and protection, level of education, etc. However, in many countries criminality increased in figures (in countries such as United Kingdom and the USA) (Siegel, 2013). In these periods of time, a social order different from those of the developed countries of Western Europe, was established in Albania, the socialist order, associated with a different political and governing order, too. After World War II, Albanian was ruled by only one political party, political pluralism was prohibited and the legal framework provided minimal respect for individual's rights and freedoms. Due to the prohibition of immigration and migration, movements of population were strictly controlled, just as the whole life of the people in general. However, in the course of these years of the Albanian state, the levels of criminality were lower compared to those after the ' $90 \mathrm{~s}$, coinciding with the installation of the capitalist order and the free market economy (Hysi, 2010). It should be emphasized that this controversy has not been noticed in developed countries. In Japan, the economic flourishment and the level of 
criminality had interchangeable relationships. In less developed areas, suchlike those of South American countries, the increase of poverty have been associated with the parallel increase of the criminality (Marotta, 2015).

So, by passing of time, it was a fact that deviation simply could neither be determined judicially nor politically, it was neither a disease nor a law; psychology and psychiatry sciences gave partial explanation to it. Even less, criminality can be considered as simply a sociological phenomenon. This casual crisis has been added to the debate over traditional and institutional response (Herrero Herrero, 2007):

- Augmenting police forces, (formal control), does not necessarily mean less criminal acts.

- Augmenting detention facilities and toughening penal convictions do not have obvious affects in the reduction of criminality.

Accepting the complexity of criminal phenomena requires the necessity of including new and fundamental elements to the science of criminology in order to make a profound analysis to the problems related to it; the victim (victimology), females (female criminology), and the surrounding environment (environmental criminology). At the end of ' $70 \mathrm{~s}$, a series of questions regarding the epistemological crises and making up the actual paradigms of criminology were answered (Van Swaaningen, 1997):

- Situational criminology; this current originates from neopositivist empiricism, (neoempiricism) as well as from neoclassicism. It describes the study of crimes as pragmatic confrontation of a criminal situation (neopositivism), which should be responded via well-defined measures. In this point of view and by means of this description, two supporting principles can be established relating to what it proposes:

o Treatment of crimes does not necessarily entail addressing its root causes; therefore, the improvement of general social and economic conditions does not mean that the majority of criminal offences ceding citizens are proportionally reduced.

o Felons should be considered as rational actors (neo-classicism), who, within their possibilities, will try to estimate circumstances and improve the performance of their actions (Burke, 2014).

Consistent to these postulates, some of the answers materialized in proposals related to some very concrete actions are obtained (commencing from the perfection of the automobile locking systems to urban landscape):

o Possibilities for criminal offences to occur are dependent on the simultaneous persistence of three factors; an individual prone to cede a certain social norm, an appropriate object and the lack of proper surveillance. Common activities (Cohen and Cohen, 2008).

o To lower the number of criminal acts, these three possibilities should be limited as much as possible; actually, citizens can themselves do more than others for their safety, by safeguarding their living spaces in the best possible way and by displaying proper conducts. The situational prevention (Gassin, Cimamonti, Bonfils, 2011).

o Taking in account the lower and relenting efficacy of the formal control organs, the informal control should be promoted. In order to achieve the intention to bring back safe ways for the citizens, constructing a livable ambiance is needed; improved urban conditions of living affect positively into the feeling of the rule of order, and promote informal control. The theory of broken windows (Curran and Renzetti, 2001).

o The most appropriate social control is the one the individuals have acquired to the extent that the most likable conduct is the one in conciliation with social norms. Self-control theories (Gottfredson and Hirschi, 1990).

- Left Realism; Successors of the current originating in the work of Marx and Engels, introduced, in '70s the term; "critical Criminology" and professed it as "the realist left" (Taylor, Walton, Young, 2013). For these actors as well as for some others, the root causes of criminality continue to originate from the social structures and they focus their attention in the relative inequality of human society; according to them, crimes do not relate as much with poverty and unemployment as they relate with the lack of choices, in a relative and concrete situation, which can be shown in any of social strata and at any economic periods, be the latter a well-being or depression period (Garcia-Pablos de Molina, 2014). In this context, individuals use individualist means to mend such abnormal conditions (Rüther, 1982). In this point of view, this new criminological paradigm, which has been professed as a legitimacy of the sub-cultural currents is in my personal opinion, a continuity of the Mertonian approach. Cultural criminology, with its approach oriented to leftist realism, focuses its 
attention to the cultural structure, considering criminality and its control as a cultural building, being the first with upward direction and an expression of the fortitude of the latter (Downward direction). (Ferrell, Hayward, Young, 2015).

At any case, crimes remain a significant and complicated problem we are to confront with, since those who suffer more by crimes are the vulnerable social groups, so all the elements composing a crime should be taken into consideration suchlike, the aggressor, victims, formal and informal control. The interaction between elements making up the "square of crime" is very complicated and many factors affecting to a crime; social, demographic, spatial and time factors (Marotta, 2015). Many agents should cooperate in the fighting against crime and the fighting should be realized in different levels; family, work, youth, police level (models of the police in community), in a democratic and equal perspective (Votey, 1996).

- Anarchist criminology; for authors of this current of criminology, emerging in '70s, criminality is a consequence of exerting power by the public administration and exploitation of markets by social structures (Hagan, 1993). They aggravate their postulates of etiquettes since they maintain that criminality is an etiquette joining conducts and individuals found in illegal situations; they also address to abolitionism, according to which the majority of conducts should not be treated penally and jails should not exist at all (Christie, 2017). In the institutional point of view, "there is the risk of hurriedly determining social problems as crimes", therefore, it is needed to raise the question on what are we considering as a crime, to deliberate about the existence of crimes, which action can be considered a crime and which cannot be considered as such, this basing on the measurement determined by society to this very aim (Ottenhof, 1995).

\section{The future of criminology}

As considered above, criminal acts are too much complicated and they intertwine issues related to political, legal, constabulary, medical, psychological and sociological nature. Deviation and criminal acts should be analyzed in terms of all these points of views and this is when criminology should be justified as science, by taking the pros and cons regarding its role as an auxiliary discipline. However, criminology should be careful not to fall into the general crises the other social and human sciences have been experiencing, and continue to act in its own domain, (to consider all actors, their ways of collaboration - society - social values - culture), to ask proper questions and to be aware of expected limitations, to fulfill its role in an unstable world in general and permanent transformation, while taking into consideration the unpredictable consequences of its interventions, so taking the shape of reflective criminology (Loeber and Welsh, 2012).

This does not entail quite another paradigm but a precautionary epistemological demand ceding any paradigm transversely. As has been emphasized in advance, positivist ideals of progress and development have caused disappointment, since, according to the fathers of modern thought, the technological and scientific progress failed to create conditions in which poverty could not exist and crime would have no meaning at all. During the late modernist period, it has been clearly understood that history is not unique, but there are many histories, there is not a unique goal and, in many cases there are not any goals at all (Marotta, 2015).

Finally, social reality is multiple and complicated, it includes interpretations of different kinds, so knowledge neither augments safety nor increases control, on the contrary, more knowledge we add within the system, more complicated gets the system per se. Consequently, this is the reason why social sciences are found in the center of the late modernism. This is the greatest paradox that should be taken into account and which entails complicated solutions. The society set up by humanity is a risk society, just as it is happening in the historical moment we are living, in which human development is jeopardizing its survival, making up the cause why we are away from achieving our ideals as well as from being positivists (Jones, 2013). Social ambiance is too complicated and dynamic; once we reflect about it or intervene into it, we change it in the way that forthcoming interventions should occur in this already turbulent and altered ambiance. This is the reason why the very complicated problems, suchlike criminality should not be taken into consideration solely basing on a general analysis of the causes, nor by providing exhausting explanation, clues that should make up the main intention of reflective criminology.

\section{References:}

[1] Becker, H. S. (1997) Outsiders. Studies on the sociology of deviance, New York: The Free Press.

[2] Bernard, T. J., Snipes, J. B. and Gerould, A. L. (2010) Vold's Theoretical Criminology, Sixth Edition, New York: Oxford University Press.

[3] Burke, R. H. (2014) An Introduction to Criminological Theory Fourth Edition, New York: Routledge. 
[4] Christie, N. (2017) Crime Control as Industry, Abingdon: Routledge Classics.

[5] Cloward, R. and Ohlin, LI. E. (2011) Delinquency and Opportunity: A theory of delinquent gangs, (New edition), New York: Routledge.

[6] Cohen, A. K. (1955) Delinquent Boys. The Culture of the Gang, New York: Free Press of Glencoe.

[7] Cohen, S. and Cohen, J. E. (2008) Against Criminology, New Brunswick, NJ: Transaction.

[8] Curran, D. J. and Renzetti, C. M (2001) Theories of Crime, second edition, Needham Heights, MA: Allyn and Bacon.

[9] Ferrell, J., Hayward, K., Young, J. (2015) Cultural Criminology: An invitation, London: Sage Publications.

[10] Ferri, E. (1953) Principi di diritto criminale, Torino: UTET, p. 481.

[11] García-Pablos de Molina, A. (2013) Criminología. Una introducción a sus fundamentos teóricos, Seventh Edition, Valencia: Tirant lo blanch.

[12] García-Pablos de Molina, A. (2014) Tratado de Criminología, Fifth Edition, Valencia: Tirant lo blanch.

[13] Garofalo, R. (1890) La Criminologie. Étude sur la nature du crime et la théorie de la pénalité, Collection Etude, Kindle Edition.

[14] Gassin, R., Cimamonti, S. dhe Bonfils, Ph. (2011) Criminologie, Seventh Edition, Paris: Dalloz.

[15] Giddens, A. (1991) Modernity and Self-Identity. Self and Society in the Late Modern Age, California: Stanford University Press.

[16] Gottfredson, M. R. dhe Hirschi, T. (1990) A general theory of crime, California: Stanford University Press.

[17] Hagan, F. E. (1993) Introduction to Criminology. Theories, Methods, and Criminal Behavior, Second Edition, Chicago: Nelson-Hall.

[18] Herrero Herrero, C. (2007) Criminología (Parte General y Especial), Third Edition, Madrid: Dykinson.

[19] Hysi, V. (2010) Kriminologjia, Second Edition, Tirana: Kristalina-KH.

[20] Jones, S. (2013) Criminology, Fifth Edition, Oxford: Oxford University Press.

[21] Kaiser, G. (1988) "La criminología, hoy", in Cuadernos de política criminal, No. 34, Madrid: Edersa: p. 43-62. Taken from: http://biblio.juridicas.unam.mx/libros/4/1755/7.pdf.

[22] Lilly, R. J., Cullen, F. T. and Ball, R. A (2015) Criminological Theory. Context and consequences, Thousand Oaks, CA: Sage Publications.

[23] Loeber, R., Welsh, B. C. (2012) The future of Criminology, New York: Oxford University Press.

[24] Lombroso, C. (1896) L'uomo delinquente. In rapporto all'antropologia, alla giurisprudenza ed alle discipline carcerarie, Fifth edition, Torino: Fratelli Bocca Editori.

[25] Mantovani, F. (1984) II problema della criminalità. Compendio di scienze criminali, Padova: Cedam.

[26] Marotta, G. (2015) Criminologia. Storia, teorie, metodi, Trento: Cedam.

[27] Merton, R. K. (1968) Social Theory and Social Structure, New York: The Free Press.

[28] Ottenhof, R. (1995) "Le concept de précocité en criminologie", in Revue de Science Criminelle et de Droit Pénal Comparé, No. 4, Sirey.

[29] Parmelee, M. $(1918,2013)$ Criminology, Classic Reprint, Leipzig: Forgotten Books. 
[30] Ponti, G. and Merzagora Betsos, I. (2008) Compendio di criminologia, Fifth Edition, Milano: Raffaello Cortina Editore.

[31] Rüther, W. (1982) "La criminalidad (o el delincuente) a traves de las definiciones sociales (o etiquetamiento)", in Nuevo Foro Penal, No. 15, Bogotá: Editorial Temis: 767-779. Taken from: http://cedpal.unigoettingen.de/data/documentacion/nuevo_foro_penal/NFP15.

[32] Siegel, L. J. (2013) Criminology. Theories, Patterns \& Typologies, Eleventh Edition, Wadsworth: Cengage Learning.

[33] Taylor, I. (1999) Crime in context. A critical Criminology of Market Societies, Cambridge: Polity Press.

[34] Taylor, I., Walton, P. and Young, J. $(1973,2013)$ The new Criminology, Abingdon: Routledge.

[35] Van Swaaningen, R. (1997) Critical Criminology. Visions from Europe, London: Sage Publications.

[36] Vattimo, G. (2009) II pensiero debole, Milano: Feltrinelli.

[37] Vattimo, G. (2011) La fine della modernità, Milano: Garzanti.

[38] Votey, H. L. (1996) "Employment, age, race and crime. A labour theoretic investigation", in Criminal Careers, (Greenberg, D. F..Ed.), Vol. II, Dartmouth: Al. 